\section{DOSE PULMONARY WEDGE RESECTION FOR LUNG CANCER ALWAYS PROVIDE WORSE SURVIVAL RESULT THAN SEGMENTECTOMY? To the Editor:}

I read with profound interest the report from Whitson and colleagues ${ }^{1}$ assessing the survival benefit of sublobar resection for invasive adenocarcinoma with bronchoalveolar (lepidic) features. Wedge resection provided less benefit in both overall survival and cancer-specific survival than does segmentectomy, which revealed a similar survival curve to that of lobectomy.

I have a different opinion regarding excision for these types of adenocarcinoma-pulmonary wedge resection with a sufficient surgical margin might be enough to attain good survival results.

In cases of segmentectomy for nonsmall-cell lung cancer, local recurrence developed less frequently in cases of sufficient distance from the tumor to the surgical margin (margin/tumor diameter ratio exceeding 1$)^{2}$ In addition, better survival has been observed in cases of wedge resection with a sufficient margin than in cases with an insufficient margin, which is closely related to presence of isolated tumor cells at the surgical margin. ${ }^{3}$

In the case of a small peripheral tumor located at the easy-to-resect region, as determined using the Lewis classification, ${ }^{4}$ both segmentectomy and wedge resection can provide a similar outcome to that of lobectomy,

\footnotetext{
The Editor welcomes submissions for possible publication in the Letters to the Editor section that consist of commentary on an article published in the Journal or other relevant issues. Authors should: - Include no more than 500 words of text, three authors, and five references. - Type with double-spacing - See http://jtcs.ctsnetjournals.org/misc/ifora.shtm for detailed submission instructions. - Submit the letter electronically via jtcvs.editorialmanager.com Letters commenting on an article published in the JTCVS will be considered if they are received within 6 weeks of the time the article was published. Authors of the article being commented on will be given an opportunity of offer a timely response ( 2 weeks) to the letter. Authors of letters will be notified that the letter has been received. Unpublished letters cannot be returned.
}

because the excision can be performed with a sufficient surgical margin.

It is crucial to reveal the survival results of excision cases according to the margin/tumor diameter ratio.

Noriyoshi Sawabata, MD, PhD

Department of General Thoracic Surgery

Osaka University Graduate School of Medicine Suita City, Osaka, Japan

\section{References}

1. Whitson BA, Groth SS, Andrade RS, Mitek MO, Maddaus MA, D'Cunha J. Invasive adenocarcinoma with bronchoalveolar features: a population-bases evaluation of the extent of resection in bronchoalveolar cell carcinoma. J Thorac Cardiovasc Surg. 2012;143:591-600.

2. Schuchert MJ, Pettiford BL, Keeley S, D'Amato TA, Kilic A, Close J, et al. Anatomic segmentectomy in the treatment of stage I nonsmall cell lung cancer. Ann Thorac Surg. 2007;84: 926-32.

3. Sawabata N, Maeda H, Matsumura A, Ohta M, Okumura M. The Thoracic Surgery Study Group of Osaka University. Clinical implications of the margin cytology findings and margin/tumor size ratio in patients who underwent pulmonary excision for peripheral non-small cell lung cancer. Surg Today. 2012;42:238-44.

4. Lewis RJ, Caccavale RJ, Sisler GE, Mackenzie JW. Video assisted thoracic surgical resection of malignant lung tumors. J Thorac Cardiovasc Surg. 1992; 104:1679-85.

http://dx.doi.org/10.1016/ j.jtcvs.2012.03.083

\section{Reply to the Editor:}

We appreciate the letter by $\mathrm{Dr} \mathrm{Sa}-$ wabata regarding our study, ${ }^{1}$ and we are delighted with his thoughtful insights into our results. We appreciate the viewpoint that there could be clinical scenarios in which wedge resection might be an adequate cancer operation. The work by Sawabata and colleagues ${ }^{2}$ investigating the ratio of tumor margin to tumor diameter has provided some of these data.

However, using the data from the Surveillance, Epidemiology, and End Results database, we were not able to calculate this ratio. A clinical role exists for a less than anatomic resection in those in whom preserving the maximum amount of pulmonary tissue or in the very frail are paramount concerns. In the setting of adenocarcinoma with bronchoalveolar features, which our report addresses, ${ }^{1}$ wedge resection might be adequate for those lesions with pure lepidic growth (adenocarcinoma in situ). This is a concern for pure lepidic growth because of spread along the alveolar planes; however, the histologic type is rather indolent. For all other lesions, those with invasive features, our data would support an anatomic resection. Data from the new International Association for the Study of Lung Cancer classification ${ }^{3}$ should be informative when they are available.

Our belief, based on our data and data from others, would be that the optimal approach for surgical resection, when possible, would be an anatomic resection with a thorough evaluation of the mediastinal lymph nodes. We thank the Editor for the opportunity to reply to Dr Sawabata's letter.

Bryan A. Whitson, MD, PhD

Jonathan D'Cunha, MD, PhD

Division of Thoracic and Foregut

Surgery

Department of Surgery

University of Minnesota

Minneapolis, Minn

\section{References}

1. Whitson BA, Groth SS, Andrade RS, Mitek MO, Maddaus MA, D'Cunha J. Invasive adenocarcinoma with bronchoalveolar features: a population-bases evaluation of the extent of resection in bronchoalveolar cell carcinoma. J Thorac Cardiovasc Surg. 2012;143:591-600.

2. Sawabata N, Maeda H, Matsumura A, Ohta M, Okumura M, The Thoracic Surgery Study Group of Osaka University. Clinical implications of the margin cytology findings and margin/tumor size ratio in patients who underwent pulmonary excision for peripheral non-small cell lung cancer. Surg Today. 2012;42:238-44.

3. Travis WD, Brambilla E, Noguchi M, Nicholson AG, Geisinger KR, Yatabe Y, et al. International Association for the Study of Lung Cancer/ American Thoracic Society/European Respiratory Society International multidisciplinary classification of lung adenocarcinoma. J Thorac Oncol. 2011;6:244-85.

http://dx.doi.org/10.1016/ j.jtcvs.2012.05.003 